\title{
KAJIAN KONSENTRASI JUS SEMANGGI DAN LAMA PERENDAMAN TERHADAP PENURUNAN LOGAM BERAT KUPANG MERAH
}

\author{
Enny Karti Basuki*, Sri Winarti \\ Staff Pengajar Teknologi Pangan Fakultas Teknik UPN "Veteran” Jawa Timur \\ Jl. Raya Rungkut Madya Gunung Anyar Surabaya 60294 \\ Email : ennykartibasuki@gmail.com
}

\begin{abstract}
Red kupang lives permanently dan eats by filtering food in waters so that it has high potential to be contaminated with heavy metals. The presence of heavy metals in kupang can cause health problems if consumed by humans. One of the efforts to reduce the heavy metal of kupang merah by adsorption method uses natural ingredients such as clover which is rich in secondary metabolites. The content of secondary metabolites in plants acts as a binder for heavy metals. The purpose of this study was to determine the concentration of clover juice dan the best time of immersion in kupang merah to reduce the level of heavy metals in kupang merah meat. This study used a complete random factorial pattern design with two factors with 2 replications. First factor: clover juice concentration 10\%, 20\%, 30\% dan second factor: contact time is 60 minutes, 90 minutes, 120 minutes. The results of clover analysis showed that fresh clover contained terpenoids/steroids, saponins, flavonoids, polyphenols dan phenols in total $86.935 \pm$ $2.004 \mathrm{mg}$ TAE/gram. The results of fresh red kupang analysis showed protein content of $9.82 \pm 0.3111 \%$, water content of $81.527 \pm 0.545 \%$, ash content of $1.840 \pm 0.014 \%$, copper metal content of $47.491 \pm 0.386 \mathrm{ppm}$, lead $21.309 \pm 1.93 \mathrm{ppm}$, chromium

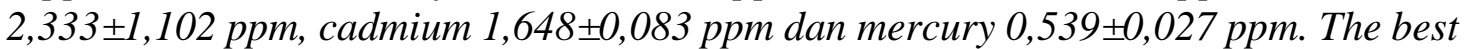
treatment in the study of the best metal content reduction at $30 \%$ clover juice concentration and 120 minutes soaking time can reduce the contamination of kupang Merah heavy metals, namely Cu to $19.862 \mathrm{ppm}$ (down 58.177\%), Pb to $0.886 \mathrm{ppm}$ (down 95.842\%), Cr to 0.758 (down 67.609\%), Cd becomes $0.813 \mathrm{ppm}$ (50.668\%), $\mathrm{Hg}$ becomes 0.024 ppm (95.547\%). The characteristics of kupang Merah meat after soaking are $9.10 \%$ protein content, $1.781 \%$ ash content dan $84.506 \%$ moisture content.
\end{abstract}

Keyword: clover, shellfish, heavy metals $\mathrm{Cu}, \mathrm{Pb}, \mathrm{Cr}, \mathrm{Cd}, \mathrm{Hg}$

\section{PENDAHULUAN}

Semakin pesatnya aktivitas industrialisasi berdampak terhadap hasil buangan limbah industri yang dapat mengakibatkan terjadinya pencemaran lingkungan. Terlebih pencemaran air yang memberikan kontribusi terhadap pelepasan logam berat beracun didalam perairan yang sebagian besar telah mengganggu biota air serta manusia. (Darmono, 2001).
Salah satu indikator pencemaran air yaitu meningkatnya kadar logam berat pada perairan. Logam berat adalah unsur unsur yang umumnya digunakan dalam industri, bersifat toksik bagi makhluk hidup dalam proses aerobik maupun anaerobik. Berdasarkan sudut pandang toksikologi, logam berat ini dapat dibagi dalam dua yaitu jenis logam berat esensial dan logam berat nonesensial. Logam berat esensial, dimana 
keberadaannya dalam jumlah tertentu sangat dibutuhkan oleh organisme hidup namun dalam jumlah berlebihan dapat menimbulkan efek racun,

contohnya yaitu $\mathrm{Zn}, \mathrm{Cu}, \mathrm{Fe}, \mathrm{Co}, \mathrm{Mn}$ dan lain sebagainya. Sedangkan logam berat non-esensial atau beracun dimana keberadaannya dalam tubuh belum diketahui manfaatnya atau bahkan bersifat racun seperti $\mathrm{Hg}, \mathrm{Cd}, \mathrm{Pb}, \mathrm{Cr}$ dan lain sebagainya (Notohadipawiro, T. 1993).

Logam-logam berat yang masuk dalam perairan akan mengalami proses pengendapan dan terakumulasi dalam sedimen, kemudian terakumulasi di dalam tubuh biota laut yang menetap dan logam berat akan terkonsentrasi ke dalam tubuh makhluk hidup dengan proses bioakumulasi dan biomagnifikasi melalui beberapa jalan, yaitu melalui saluran pernapasan, saluran makanan dan melalui kulit. Kelompok organisme yang mampu mengakumulasi logam berat adalah bivalvia. Kemampuan tersebut menjadikan bivalvia menjadi bioindikator suatu perairan (Dahuri et al. 1996 dalam Putri, 2010).

Kupang merupakan salah satu biota laut yang dapat digunakan sebagai bioindikator tingkat pencemaran air laut. Sifat kupang yang menetap di suatu tempat karena pergerakan yang lambat, dan bersifat filter feeder non selective, yaitu menyaring air untuk mendapatkan makanan, menyebabkan kerang rentan terkena bahan polusi air, terutama logam berat yang bersifat akumulatif dalam tubuh kerang (Darmono, 2001). Dalam pertumbuhannya, kupang dapat mengakumulasi logam berat dalam tubuhnya jika hidup pada perairan yang terkontaminasi logam berat (Suwignyo, 2005).

Kupang masuk dalam kelompok kerang-kerangan serta memiliki kandungan gizi yang cukup tinggi.
Masyarakat khususnya daerah Jawa Timur banyak menggemari kuliner berbahan dasar kupang, dengan sentra produksi kupang di wilayah Sidoarjo, Surabaya, Gresik, dan Pasuruan. Potensi produksi kupang di Sidoarjo berkisar 10.664.600 kg pada tahun 2010 (Anonymous, 2010).

Tinggginya tingkat konsumsi daging kupang maka perlu dilakukan upaya penurunan kadar logam berat pada kupang. Berbagai metode untuk mengurangi cemaran logam seperti penukaran ion, penyerapan dengan karbon aktif, dan pengendapan secara elektrolisis telah dilakukan untuk menyerap bahan pencemar beracun, tetapi cara ini membutuhkan biaya yang besar dalam pengoperasiannya (Marganof, 2003). Berbagai metode telah dikembangkan sebagai upaya untuk mengurangi kadar logam berat yang melampaui ambang batas, salah satunya adalah dengan metode adsorpsi. Adsorpsi merupakan terserapnya suatu zat baik molekul atau ion (adsorbat) pada permukaan adsorben (Hendra, 2008). Adsorpsi memiliki beberapa kelebihan jika dibandingkan dengan metode lain, diantaranya memerlukan biaya relatif murah, prosesnya sederhana, efektifitas dan efisiennya tinggi serta adsorbennya dapat digunakan kembali (regenerasi) (Rahmalia dkk, 2009). Adsorpsi logam berat terjadi karena adanya interaksi antara gugus fungsi aktif dari adsorben, sehingga struktur kimia dari adsorben akan mempengaruhi proses adsorpsi.

Berdasarkan uraian di atas, perlu dilakukan penelitian tentang pengaruh perendaman jus semanggi terhadap kadar merkuri, kadmium, tembaga, kromium, timbal dan karakteristik daging kupang merah sehingga dapat memberikan hasil yang terbaik.

Tujuan penelitian ini untuk mengetahui konsentrasi jus semanggi dan lama waktu perendaman terhadap 
penurunan kadar logam berat pada daging kupang merah.

\section{METODE}

Dalam penelitian ini digunakan Rancangan Acak Lengkap (RAL) yang terdiri dari 2 faktor, yaitu faktor I konsentrasi jus semanggi $(10 \%, 20 \%$, $30 \%$ ) dan faktor II waktu kontak (60 menit, 90 menit, 120 menit). Masing-masing kombinasi perlakuan diulang sebanyak 2 kali. Data yang diperoleh dianalisis menggunakan analisis ragam (ANOVA), apabila terdapat perbedaan nyata antar perlakukan dilanjutkan dengan uji DMRT (Duncan't Multiple Range Test). Parameter yang diamati yaitu uji skrinning fitokimia semanggi segar, uji kadar protein kupang (AOAC, 2005), uji total fenol semanggi segar (Ghasemi et al., 2009), uji kadar air kupang (AOAC, 2005), uji kadar abu kupang merah (AOAC, 2005) dan uji logam berat pada kupang merah metode AAS (mercury analyzer dan SNI 2354.5:2011).

\section{Tempat Penelitian}

Penelitian dilakukan di Laboratorium Analisa Pangan dan Laboratorium Teknologi Pengolahan Pangan Jurusan Teknologi Pangan, Fakultas Teknik, UPN "Veteran" Jawa Timur, Laboratorium Pengujian Terpadu UPN "Veteran" Jawa Timur untuk analisa kadar protein kupang merah, Laboratorium Kimia Analitik Jurusan Kimia Fakutas Matematika dan Ilmu Pengetahuan Alam Universitas Gadjah Mada Yogyakarta untuk analisa cemaran logam berat tembaga dan timbal dan Laboratorium Penelitian dan Pengujian Terpadu Universitas Gadjah Mada Yogyakarta untuk analisa cemaran logam berat merkuri.

\section{Bahan dan Alat Penelitian}

Bahan baku yang digunakan dalam penelitian ini adalah semanggi (Marsilea crenata) dan kupang, sedangkan bahan kimia untuk analisa meliputi: aquades, asam tanat, reagen folin ciocalteu $(50 \%$ $\mathrm{v} / \mathrm{v})$, etanol 96\%, Na2CO3. Alat-alat yang digunakan blender, kain saring, pipet, gelas ukur, cawan petri, erlemeyer, thermometer, , pengaduk, loyang, botol timbang, erlenmeyer, gelas beker, cabinet dryer, furnice, AAS (Atomic Absorption Spectroscopy), oven, desikator, Spektrofotometer UV, labu takar, corong kaca, gelas ukur, pipet volume, neraca analitik, blender.

\section{Prosedur Penelitian}

1. Tahapan awal proses penelitian dimulai dengan persiapan bahan baku yaitu semanggi. Semanggi segar dipisahkan dari akarnya dan dipilih semanggi yang masih hijau segar.

2. Semanggi yang telah disortasi kemudian dicuci dengan air bersih sampai kotoran-kotoran yang menempel seperti tanah dan lumpur hilang.

3. Proses selanjutnya yaitu pembuatan jus semanggi dengan konsentrasi $10 \%$, $20 \%, 30 \%$.

4. Sebelum dilakukan perlakuan perendaman, kupang terlebih dahulu dicuci lalu dipisahkan dari cangkangnya. Daging kupang dilakukan analisa bahan baku yang meliputi analisa kadar air, kadar abu, kadar protein dan analisa kadar logam berat $\mathrm{Cu}, \mathrm{Pb}, \mathrm{Cr}, \mathrm{Cd}$ dan $\mathrm{Hg}$ awal.

5. Tahap selanjunya yaitu perlakuan perendaman daging kupang segar pada jus semanggi dengan konsentrasi $10 \%$, $20 \%, 30 \%$ dan lama waktu perendaman yaitu 60 menit, 90 menit dan 120 menit.

6. Daging kupang yang telah dilakukan perlakuan perendaman kemudian dicuci dengan aquades sampai bersih lalu ditiriskan.

7. Daging kupang yang telah bersih kemudian dianalisa kadar logam $\mathrm{Pb}$, 
$\mathrm{Cu}, \mathrm{Cr}, \mathrm{Cd}, \mathrm{Hg}$ menggunakan AAS dan mercury analyzer.

\section{HASIL DAN PEMBAHASAN}

Pada penelitian ini bahan baku yang digunakan terdiri atas 2 bahan yaitu semanggi segar dan daging kupang merah. Analisa yang dilakukan pada penelitian ini dimulai dari analisa bahan baku yaitu skrinning fitokimia semanggi segar dan kadar total fenol semanggi segar yang dapat dilihat pada Tabel. 1 dibawah ini.

Tabel 1 Analisa bahan baku

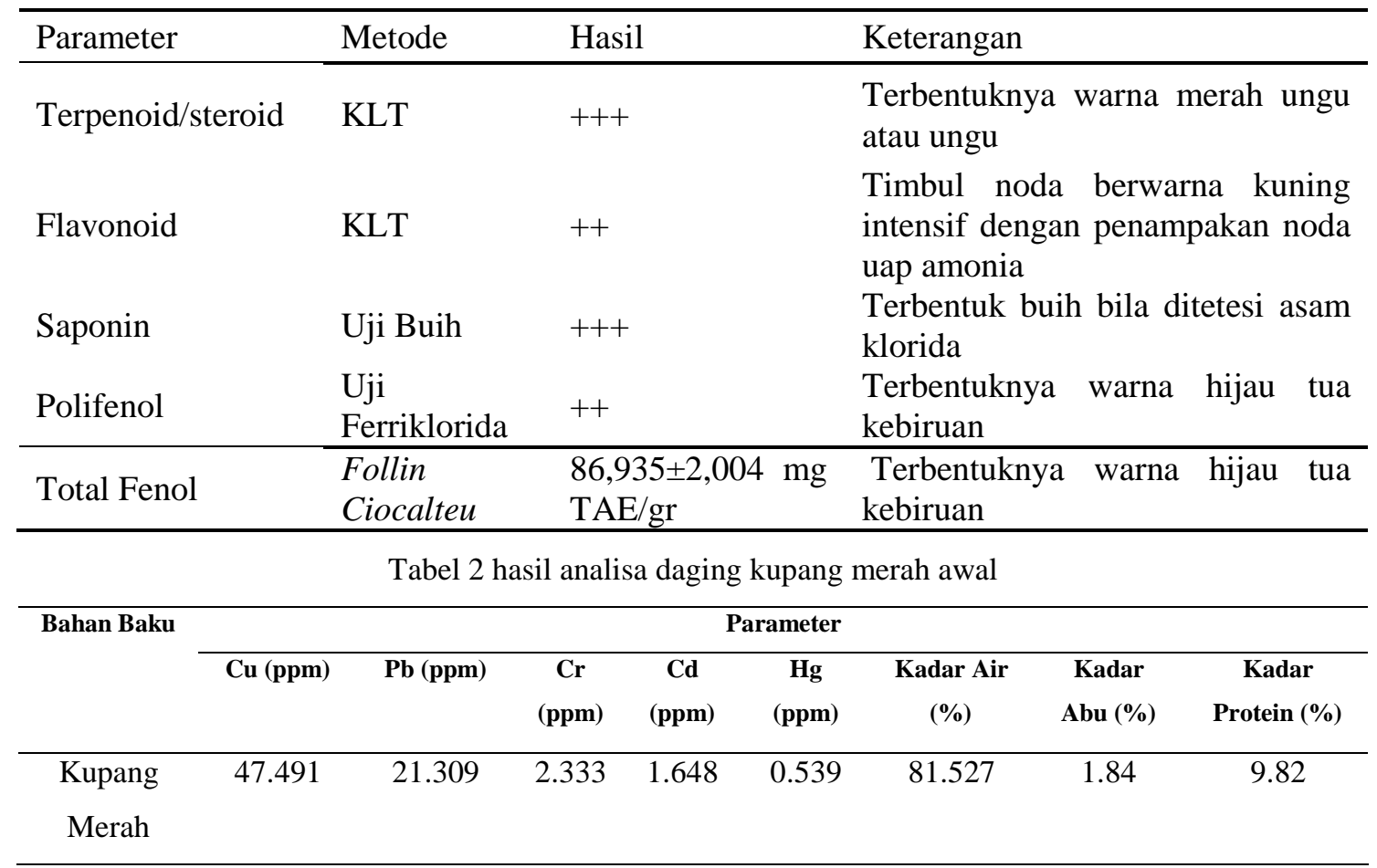

Senyawa fitokimia merupakan senyawa bioaktif alami yang terdapat pada tanaman yang dapat berperan sebagai nutrisi dan serat alami yang dapat mencegah penyakit (Harborne, 1987). Uji fitokimia bertujuan untuk mengetahui komponen bioaktif yang terdapat pada ekstrak kasar semanggi. Hasil skrinning fitokimia semanggi menunjukkan bahwa semanggi mengandung senyawa terpenoid/steroid, saponin, flavonoid dan polifenol hal serupa dilaporkan pada penelitian Gopalakrishnan dan Udayakumar (2017) yang menggunakan Marselia quadrifolia sebagai bahan yang diuji mengandung flavonoid, saponin, flavonoid dan polifenol.

Fenol atau asam korbalat adalah zat kristal yang tidak berwarna sampai berwarna merah muda cerah yang memiliki bau tajam dan khas (Harborne, 1987). Hasil penelitian menunjukkan bahwa total fenol pada semanggi sebesar $86.935 \pm 2.004 \mathrm{mg}$ TAE/gr lebih kecil dari penelitian Pepsi dkk (2012) sebesar 165.0 $\pm 50.9 \quad \mathrm{mg}$ TAE/gram, hal ini dapat disebabkan oleh beberapa faktor yaitu kondisi alamiah senyawa tersebut, metode ekstraksi yang digunakan, ukuran partikel sampel, kondisi dan waktu penyimpanan, lama waktu ekstraksi, serta perbandingan jumlah pelarut terhadap jumlah sampel (Harborne, 1987).

Selain semanggi bahan baku pada penelitian ini yaitu kupang merah. Analisa awal pada kupang merah meliputi kadar protein, kadar air, kadar abu dan analisa logam berat tembaga, timbal, kromium, 
kadmium dan merkuri pada kupang merah tercemar. Hasil analisa awal kupang merah dapat dilihat pada Tabel. 2.

Kadar air adalah banyaknya air yang terkandung dalam bahan yang dinyatakan dalam persen. Kadar air juga salah satu karakteristik yang sangat penting pada bahan pangan, karena air dapat mempengaruhi penampakan, tekstur dan cita rasa pada bahan pangan (Sandjaja, 2009). Kadar air daging kupang merah pada penelitian ini sebesar $8.527 \% \pm 0.545$ tidak berbeda jauh dengan penelitian Ulma (2014) yaitu pada daging kupang segar sebesar $81.57 \pm 0,02 \%$. Penelitian Martin et al., (1991) dalam Arnanda dkk (2005) menyatakan bahwa kadar air dalam tubuh hewan air berkisar antara 50\%-90\% berat basah. Sedangkan menurut Sikorski (1990) Arnanda dkk (2005). Kadar air dalam tubuh ikan dan hewan moluska laut berkisar antara 50\%-85\% tergantung dari jenis spesies dan kondisi nutrisi dalam tubuhnya.

Kadar abu merupakan sisa zat anorganik dari proses pembakaran komponen organik bahan pangan. Kadar abu dari suatu bahan menunjukkan kandungan mineral yang terdapat dalam bahan tersebut (Andarwulan dkk., 2011). Hasil analisa kadar abu daging kupang merah sebesar $1.840 \% \pm 0.014$ tidak berbeda jauh dengan penelitian Ulma (2014) sebesar $1.86 \% \pm 0.01$. Penelitian Sikorski (1990) Arnanda dkk (2005), menyatakan bahwa ikan maupun hewan invertebrata laut memiliki kadar abu sekitar $0.6-1.5 \%$ berat basah. Selain itu dapat dikatakan bahwa kerang bulu dengan ukuran lebih besar, umurnya lebih tua sehingga kerang tersebut lebih banyak menyimpan mineral daripada ukuran yang lebih kecil sebagaimana sifat kerang yang mengakumulasi mineral dari lingkungannya (Mance,1990) dalam Arnanda dkk (2005).
Hasil analisa kadar protein daging kupang merah sebesar 9.82\% \pm 0.3111 sedikit lebih rendah dibandingkan penelitian Ulma (2014) sebesar $11.84 \% \pm$ 0.05. Penelitian Anthony (1983) dalam Arnanda dkk (2005), menyatakan bahwa kadar protein dalam beberapa hewan moluska cukup rendah berkisar antara 8\%9\%. Sedangkan Sikorski (1990) dalam Arnanda dkk (2005), mengatakan bahwa kadar protein pada hewan laut baik ikan maupun hewan invertebrata berkisar antara $11-24 \%$, dimana protein ini merupakan protein kasar yang besarnya tergantung dari spesiesnya, kondisi nutrisi dan tipe ototnya.

Hasil analisa logam merkuri $(\mathrm{Hg})$ lebih besar dibandingkan penelitian yang dilakukan oleh Edward, 2017 sebesar 0.42 ppm, kadmium (Cd) lebih besar dibandingkan penelitian yang dilakukan oleh Adriyani, 2009 dan tembaga $(\mathrm{Cu})$ lebih besar dibandingkan penelitian yang dilakukan oleh Cahyani dkk., 2012. Perbedaan hasil analisa dapat terjadi akibat proses akumulasi logam berat dalam tubuh hewan air dipengaruhi oleh banyak faktor antara lain yaitu konsentrasi logam berat dalam air, pH air (Wahyuni dkk., 2013), tingkat pencemaran air dalam bentuk COD (chemical oxygen demand), jenis hewan air atau spesies (Arifin, 2011), bobot tubuh/ukurannya dan fase hidup (telur dan larva).

Setelah dilakukan perlakuan perendaman pada larutan jus semanggi, daging kupang merah dilakukan analisa meliputi analisa kadar logam berat tembaga, timbal, kromium, kadmium, merkuri, kadar air, kadar abu dan kadar protein. Hasil analisa daging kupang merah setelah perlakuan dapat dilihat pada Tabel. 3 dibawah ini. 
Tabel 3 hasil analisa daging kupang merah setelah perendaman

\begin{tabular}{|c|c|c|c|c|c|c|c|c|c|}
\hline \multicolumn{2}{|c|}{ PERLAKUAN } & \multicolumn{8}{|c|}{ PARAMETER } \\
\hline Kons. Jus Semanggi (\%) & Waktu Kontak (menit) & $\begin{array}{c}\text { Kadar } \\
\mathrm{Cu} \\
\text { kupang } \\
\text { (ppm) }\end{array}$ & $\begin{array}{c}\text { Kadar } \\
\mathrm{Pb} \\
\text { kupang } \\
(\mathrm{ppm})\end{array}$ & $\begin{array}{c}\text { Kadar } \\
\mathrm{Cr} \\
\text { kupang } \\
\text { (ppm) }\end{array}$ & $\begin{array}{c}\text { Kadar } \\
\text { Cd } \\
\text { kupang } \\
\text { (ppm) }\end{array}$ & $\begin{array}{c}\text { Kadar } \\
\mathrm{Hg} \\
\text { kupang } \\
\text { (ppm) }\end{array}$ & $\begin{array}{c}\text { Kadar } \\
\text { Protein } \\
\text { kupang } \\
(\%)\end{array}$ & $\begin{array}{c}\text { Kadar } \\
\text { Air } \\
\text { kupang } \\
(\%)\end{array}$ & $\begin{array}{c}\text { Kadar } \\
\text { Abu } \\
\text { kupang } \\
(\%)\end{array}$ \\
\hline \multirow{4}{*}{$10 \%$} & 60 menit & 25.349 & 5.704 & 2.287 & 1.634 & 0.280 & 9.81 & 81.568 & 1.837 \\
\hline & 90 menit & 23.939 & 4.053 & 1.903 & 1.541 & 0.236 & 9.58 & 81.687 & 1.810 \\
\hline & 120 menit & 22.453 & 2.931 & 1.584 & 1.256 & 0.145 & 9.52 & 82.287 & 1.821 \\
\hline & 60 menit & 22.892 & 3.128 & 1.861 & 1.564 & 0.175 & 9.56 & 82.776 & 1.819 \\
\hline \multirow[t]{3}{*}{$20 \%$} & 90 menit & 22.586 & 2.702 & 1.281 & 1.135 & 0.132 & 9.32 & 82.882 & 1.796 \\
\hline & 120 menit & 21.936 & 1.693 & 1.163 & 1.059 & 0.084 & 9.18 & 83.290 & 1.804 \\
\hline & 60 menit & 21.425 & 1.659 & 1.189 & 1.105 & 0.103 & 9.31 & 83.655 & 1.793 \\
\hline \multirow[t]{2}{*}{$30 \%$} & 90 menit & 20.619 & 1.219 & 1.018 & 0.880 & 0.030 & 9.10 & 84.094 & 1.781 \\
\hline & 120 menit & 19.862 & 0.886 & 0.758 & 0.813 & 0.024 & 9.12 & 84.506 & 1.786 \\
\hline
\end{tabular}

Perendaman Kupang Merah dalam Jus Semanggi Berbagai Konsentrasi

Pada penelitian ini daging kupang merah dilakukan perendaman dalam jus semanggi konsentrasi 10\%, 20\%, 30\% dengan lama waktu perendaman 60 menit, 90 menit, 120 menit. Hasil analisa rata-rata kadar logam berat dan karakteristik daging kupang merah setelah perendaman dalam jus semanggi dapat dilihat pada Tabel. 3 diatas. Hasil analisa logam berat $\mathrm{Cu}$ setelah perendaman dalam jus semanggi $10 \%$, 20\%, 30\% berkisar antara 25.349-19.862 ppm mengalami penurunan $46.624 \%$ $58.177 \%$ dari kadar $\mathrm{Cu}$ awal. Bila dibandingkan SK Dirjen POM No.03725/B/SK/VII/89 tanggal 10 Juli 1989 tentang Batas Maksimum Cemaran Logam dalam Makanan yang menetapkan kadar maksimum $\mathrm{Cu}$ dalam kerang yang dapat dikonsumsi yaitu sebesar $20 \mathrm{ppm}$, maka kadar $\mathrm{Cu}$ dalam sampel kupang merah setelah dilakukan perendaman dalam jus semanggi konsentrasi $30 \%$ dan waktu perendaman 120 menit masih dalam batas aman untuk dikonsumsi yaitu sebesar $19.862 \mathrm{ppm}$ atau mengalami penurunan sebesar $58.177 \%$ dari kadar awal $\mathrm{Cu}$.
Berdasarkan hasil analisis ragam ANOVA diketahui bahwa terdapat interaksi yang sangat nyata $(\mathrm{p}<0.05)$ antara perlakuan perbedaan konsentrasi jus semanggi dan waktu kontak terhadap nilai kadar tembaga kupang merah. Demikian pula antara masing-masing perlakuan mempunyai pengaruh nyata.

Hasil analisa logam berat $\mathrm{Pb}$ setelah perendaman dalam jus semanggi $10 \%$, $20 \%, 30 \%$ berkisar antara 25.349-19.862 ppm mengalami penurunan $73.232 \%$ $95.842 \%$ dari kadar $\mathrm{Pb}$ awal. Bila dibandingkan SNI 7387:2009 tentang Batas Maksimum Cemaran Logam Berat dalam Pangan yang menetapkan kadar maksimum $\mathrm{Pb}$ dalam kerang yang dapat dikonsumsi yaitu sebesar $2 \mathrm{ppm}$, maka kadar $\mathrm{Pb}$ dalam sampel kupang merah setelah dilakukan perendaman dalam jus semanggi konsentrasi $20 \%$ dan waktu perendaman 120 menit masih dalam batas aman untuk dikonsumsi yaitu sebesar 1.693 ppm atau mengalami penurunan sebesar $92.055 \%$ dari kadar awal $\mathrm{Pb}$. Berdasarkan hasil analisis ragam ANOVA diketahui bahwa terdapat interaksi yang nyata $(\mathrm{p}<0.05)$ antara perlakuan perbedaan 
konsentrasi jus semanggi dan waktu kontak terhadap nilai kadar timbal kupang merah. Demikian pula antara masing-masing perlakuan mempunyai pengaruh nyata.

Hasil analisa logam berat $\mathrm{Cr}$ setelah perendaman dalam jus semanggi $10 \%$, $20 \%, 30 \%$ berkisar antara 2.287-0.758 ppm mengalami penurunan $1,972 \%$ $67.509 \%$ dari kadar $\mathrm{Cr}$ awal. Bila dibandingkan SNI 7387:2009 tentang Batas Maksimum Cemaran Logam Berat dalam Pangan yang menetapkan kadar maksimum $\mathrm{Cr}$ dalam kerang yang dapat dikonsumsi yaitu sebesar $2 \mathrm{ppm}$, maka kadar $\mathrm{Cr}$ dalam sampel kupang merah setelah dilakukan perendaman dalam jus semanggi konsentrasi $10 \%$ dan waktu perendaman 90 menit masih dalam batas aman untuk dikonsumsi yaitu sebesar $1.903 \mathrm{ppm}$ atau mengalami penurunan sebesar $18.431 \%$ dari kadar $\mathrm{Cr}$ awal. Berdasarkan hasil analisis ragam ANOVA diketahui bahwa terdapat interaksi yang nyata $(\mathrm{p}<0.05)$ antara perlakuan perbedaan konsentrasi jus semanggi dan waktu kontak terhadap nilai kadar kromium kupang merah. Demikian pula antara masingmasing perlakuan mempunyai pengaruh nyata.

Hasil analisa logam berat $\mathrm{Cd}$ setelah perendaman dalam jus semanggi $10 \%$, $20 \%$, 30\% berkisar antara 1.634-0.813 ppm mengalami penurunan $0.849 \%$ $50.668 \%$ dari kadar $\mathrm{Cd}$ awal. Bila dibandingkan SNI 7387:2009 tentang Batas Maksimum Cemaran Logam Berat dalam Pangan yang menetapkan kadar maksimum $\mathrm{Cd}$ dalam kerang yang dapat dikonsumsi yaitu sebesar $1 \mathrm{ppm}$, maka kadar Cd dalam sampel kupang merah setelah dilakukan perendaman dalam jus semanggi konsentrasi $30 \%$ dan waktu perendaman 90 menit masih dalam batas aman untuk dikonsumsi yaitu sebesar $0.880 \mathrm{ppm}$ atau mengalami penurunan sebesar $46.602 \%$ dari kadar Cd awal. Berdasarkan hasil analisis ragam ANOVA diketahui bahwa terdapat interaksi yang nyata $(\mathrm{p}<0.05)$ antara perlakuan perbedaan konsentrasi jus semanggi dan waktu kontak terhadap nilai kadar kadmium kupang merah. Demikian pula antara masingmasing perlakuan mempunyai pengaruh nyata.

Hasil analisa logam berat $\mathrm{Hg}$ setelah perendaman dalam jus semanggi $10 \%$, $20 \%, 30 \%$ berkisar antara $0.280-0.024$ ppm mengalami penurunan $48.052 \%$ $95.547 \%$ dari kadar $\mathrm{Hg}$ awal. Bila dibandingkan SNI 7387:2009 tentang Batas Maksimum Cemaran Logam Berat dalam Pangan yang menetapkan kadar maksimum $\mathrm{Hg}$ dalam kerang yang dapat dikonsumsi yaitu sebesar 1 ppm, maka kadar $\mathrm{Hg}$ dalam sampel kupang merah setelah dilakukan perendaman dalam jus semanggi konsentrasi $10 \%$ dan waktu perendaman 60 menit masih dalam batas aman untuk dikonsumsi yaitu sebesar $0.280 \mathrm{ppm}$ mengalami penurunan sebesar $48.052 \%$ dari kadar Cd awal. Berdasarkan hasil analisis ragam ANOVA diketahui bahwa terdapat interaksi yang nyata $(\mathrm{p}<0.05)$ antara perlakuan perbedaan konsentrasi jus semanggi dan waktu kontak terhadap nilai kadar merkuri kupang merah. Demikian pula antara masingmasing perlakuan mempunyai pengaruh nyata.

Penurunan logam berat pada daging kupang merah setelah perendaman pada jus semanggi terjadi karena pengaruh konsentrasi jus semanggi yang semakin meningkat akan meningkatkan jumlah senyawa flavonoid dan polifenol yang terdapat pada jus semanggi sehingga mampu untuk mengikat logam berat dan semakin lama waktu perendaman semakin banyak logam berat yang terikat pada senyawa flavonoid dan polifenol sehingga menyebabkan kadar logam berat pada kupang merah menurun. Berdasarkan penelitian Ren et al., (2008) dalam Kasprzak et al., (2013) tentang kompleks 
logam dengan struktur flavonoid, diketahui bahwa kemampuan mengkhelat logam $\mathrm{Fe}$ dari struktur kuersetin memiliki energi dan kestabilan yang paling besar untuk mengkhelat logam dibandingkan kemampuan mengkhelat logam $\mathrm{Cu}$. Menurut Kosiorek-Rupinska et al.,(2006) dalam Kasprzak et al., (2013) sebagian besar flavonoid pada tanaman mampu membentuk kompleks logam yang stabil melalui berbagai gugus $\mathrm{OH}$ dan karbonilnya. Adanya hidroksilasi dan posisi relatif dari gugus $\mathrm{OH}$ merupakan faktor penting yang menentukan kemampuan flavonoid. Kekuatan flavonoid bergantung pada jumlah dan posisi dari gugus $\mathrm{OH}$ yang terdapat pada molekulnya (Puspitasari dkk, 2016). Mekanisme serapan yang terjadi antara gugus $-\mathrm{OH}$ yang terikat pada permukaan dengan ion logam yang bermuatan positif merupakan mekanisme pertukaran ion. Interaksi antara gugus - $\mathrm{OH}$ dengan ion logam juga memungkinkan melalui mekanisme pembentukan kompleks koordinasi karena atom oksigen pada gugus $-\mathrm{OH}$ mempunyai pasangan elektron bebas (Mohamad, 2011). Dalam struktur beberapa flavonoid terdapat tiga posisi koordinasi potensial untuk proses pengkhelatan yaitu: a) Antara gugus 5hidroksi dan 4-karbonil; b) Antara gugus 3hidroksi dan 4-karbonil; c) Antara 3', kelompok 4'-hidroksi di cincin B (Symonowicz et al., 2012).

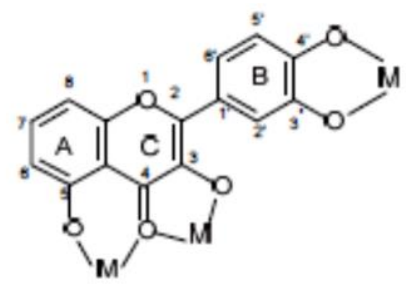

Gambar 1 Koordinasi potensial untuk pengkhelatan logam pada struktur flavonoid (Symonowicz et al., 2012)

Hasil analisa kadar protein setelah perendaman dalam jus semanggi $10 \%$,
$20 \%, 30 \%$ berkisar antara 9.81-9.12\%. Berdasarkan hasil analisis ragam ANOVA diketahui bahwa terdapat interaksi yang nyata $(\mathrm{p}<0.05)$ antara perlakuan perbedaan konsentrasi jus semanggi dan waktu kontak terhadap nilai kadar protein kupang merah. Demikian pula antara masing-masing perlakuan mempunyai pengaruh nyata. Penurunan kadar protein dalam daging kupang merah disebabkan oleh efek samping penyerapan logam berat oleh senyawa bioaktif pada jus semanggi sehingga komponen mineral pada saat perendaman terlarut bersamaan dengan terlarutnya logam berat. Sifat kelarutan protein juga tergantung pada jenis protein, jenis pelarut, $\mathrm{pH}$, konsentrasi, muatan ion, dan suhu (Andarwulan et al. 2011). Menurut Finger dan Smith (1987) dalam Hayati (2012), kelenjar pencernaan hewan laut yaitu cepalopoda memiliki sejumlah sifat yang mirip dengan logam dan mampu berikatan dengan metallotionin. Soto et al., (2007) dalam Hayati (2012) melaporkan bahwa protein metallotionin (protein MT) adalah protein sistein dengan berat molekul rendah, mudah larut, tahan terhadap terhadap suhu tinggi (protein termofilik), kaya akan unsur belerang (lebih dari 30\%) serta memiliki afinitas yang kuat dengan ikatan logam. Komponen protein yang terlarut tersebut terdiri dari protein yang bersifat larut air terutama sarkoplasma.

Hasil analisa kadar air setelah perendaman dalam jus semanggi $10 \%$, $20 \%$, 30\% berkisar antara 81.568$84.506 \%$. Berdasarkan hasil analisis ragam ANOVA diketahui bahwa terdapat interaksi yang nyata $(\mathrm{p}<0.05)$ antara perlakuan perbedaan konsentrasi jus semanggi dan waktu kontak terhadap nilai kadar air kupang merah. Demikian pula antara masing-masing perlakuan mempunyai pengaruh nyata. Peningkatan kadar air pada daging kupang merah disebabkan karena terjadi proses difusi saat perendaman kupang merah pada larutan jus semanggi. Semakin lama proses 
perendaman daging kupang dalam larutan tepung semanggi maka semakin lama proses difusi dari konsentrasi tinggi ke konsentrasi rendah pada jus semanggi. Menurut Al Chusein dan Ibrahim (2012) makin lama waktu perendaman makin tinggi kadar air yang terdapat dalam daging kerang. Kenaikan kadar air dalam daging kerang diduga karena air masuk dan menggantikan ion logam. Hal ini juga didukung oleh Widiyanti (2004) efek perendaman jeruk nipis juga berpengaruh terhadap komposisi proksimat kerang hijau yaitu terjadinya peningkatan kadar air setelah dilakukan perendaman jeruk nipis.

Hasil analisa kadar abu setelah perendaman dalam jus semanggi $10 \%$, $20 \%, 30 \%$ berkisar antara 1.837-1.786\%. Berdasarkan hasil analisis ragam ANOVA diketahui bahwa terdapat interaksi yang sangat nyata $(\mathrm{p}<0.05)$ antara perlakuan perbedaan konsentrasi jus semanggi dan waktu kontak terhadap nilai kadar abu kupang merah. Demikian pula antara masing-masing perlakuan mempunyai pengaruh nyata. Semakin tinggi konsentrasi larutan jus semanggi dan semakin lama waktu kontak, maka kadar abu daging kupang akan semakin menurun. Hal ini disebabkan karena kondisi $\mathrm{pH}$ larutan tepung semanggi yang berkisar pada pH 5.2 yang bersifat asam lemah serta terjadinya proses difusi dari larutan tepung semanggi konsentrasi tinggi ke konsentrasi rendah sehingga mengakibatkan kadar abu menurun. Ismangil dan Hanudin (2005) dalam Hayati (2012) menyatakan bahwa mineral umumnya adalah senyawa anorganik yang berupa padatan dan berbentuk kristal. Apabila mineral tersebut mengalami pelarutan, maka reaksi yang berlangsung adalah difusi. Reaksi ini merupakan reaksi antara atom-atom pada lapisan permukaan kristal (yang terikat kuat oleh atom di lapisan bagian dalamnya) dengan air atau larutan yang reaktif yang berada di luar kristal. Hasilnya, pada permukaan mineral terjadi penyingkiran atom penyusun yang kemudian masuk ke dalam air atau larutan. Selanjutnya dalam lapisan tersebut mencari kesetimbangan baru dan pada bagian larutan terjadi penambahan atom (ion) atau peningkatan konsentrasi.

\section{KESIMPULAN}

Hasil skrining fitokimia semanggi (Marsilea crenata) mengandung senyawa terpenoid/steroid, saponin,flavonoid, polifenol dan kadar total fenol sebesar $86.935 \pm 400 \mathrm{mg}$ TAE/ gram. Hasil analisa kadar proksimat dan kadar logam awal kupang merah (Masculita senhausia) yaitu kadar protein sebesar 9.82 $0.3111 \%$, kadar air sebesar $81.527 \pm 0.545 \%$,kadar abu sebesar $1.840 \pm 0.014 \%$, kadar logam tembaga $(\mathrm{Cu})$ sebesar $47.491 \pm 0.386 \mathrm{ppm}$, timbal sebesar 21.309 $\pm 1.963 \mathrm{ppm}$, kromium (Cr) sebesar 21.309 $\pm 1.963 \mathrm{ppm}$, kromium $(\mathrm{Cr})$ sebesar 2.333 $\pm 1.102 \mathrm{ppm}$ dan kadmium $(\mathrm{Cd})$ sebesar 1.648 \pm 0.083 ppm dan merkuri (Hg) sebesar 0.539 $\pm 0.027 \mathrm{ppm}$.

Daging kupang merah setelah dilakukan perendaman pada jus semanggi $10 \%, 20 \%, 30 \%$ dan lama waktu perendaman 60 menit, 90 menit dan 120 menit diperoleh perlakuan terbaik pada konsentrasi jus semanggi $30 \%$ waktu perendaman 120 menit yang dapat menurunkan cemaran logam berat pada kupang merah yaitu $\mathrm{Cu}$ dari $47.491 \mathrm{ppm}$ menjadi 19.862 ppm (turun 58.177\%), $\mathrm{Pb}$ dari 21.309 ppm menjadi 0,886 ppm (turun 95.842\%), Cr dari 2.333 ppm menjadi 0.758 ppm (turun 67.509\%), Cd dari 1.648 ppm menjadi $0.813 \mathrm{ppm}$ (turun 50.668\%), $\mathrm{Hg}$ dari $0.539 \mathrm{ppm}$ menjadi $0.024 \mathrm{ppm}$ (turun 95.547\%). Karakteristik daging kupang merah setelah dilakukan perendaman dalam jus semanggi yaitu kadar protein 9,10\%, kadar abu $1.781 \%$ dan kadar air dari $84.506 \%$ 


\section{SARAN}

Disarankan untuk dilakukan analisa fitokimia pada semanggi secara kuantitatif menggunakan alat yang lebih canggih seperti GCMS maupun HPLC untuk mengetahui kadar senyawa metabolit sekundernya secara pasti dan pemeriksaan kandungan logam berat pada biota laut di sepanjang perairan Sidoarjo dan Surabaya.

\section{UCAPAN TERIMA KASIH}

Penulis mengucapkan terimakasih kepada pihak yang telah mendanai penelitian ini sehingga penelitian ini dapat berjalan lancar dan terselesaikan

\section{DAFTAR PUSTAKA}

Al Chusein, A.F. dan R. Ibrahim. 2012. Lama Perendaman Daging Kerang Darah (Anadara granosa) Rebus dalam Larutan Alginat Terhadap Pengurangan Kadar Kadmium.Jurnal Saintek Perikanan, 8(1): 20-26.

Andarwulan, N, Kusnandar, F, Herawati, D. 2011. Analisis Pangan. Dian Rakyat. Jakarta.

Anonymous. 2010. Kabupaten Sidoarjo Dalam Angka.http://dinas-perikanan sidoarjokab.go.id/kabupatensidoarjo- dalam-angka.html

Arnanda, A.D., Ambariyanto., Ridlo, A. 2005. Fluktuasi Kandungan Proksimat Kerang Bulu (Andara inflata reeve) di Perairan Pantai Semarang. Jurusan Ilmu Kelautan. FPIK. Universitas Diponegoro. Semarang. Vol. 10(2): 78-84

AOAC, Association of Official Analytical Chemist. 2005. Official Method of Analysis of the Association of Official Analytical of Chemist. Arlington :The Association of Official Analytical Chemist, Inc.

Arifin, M. 2009. Analisis Mikroskopi dan Kandungan Mineral Semanggi Air Marsilea crenata Presl. (Marsileaceae). Skripsi tidak diterbitkan. Institut Pertanian Bogor. Bogor.

Cahyani, M.D, Azizah, R.T.N dan Yulianto, B. 2012. Studi Kandungan Logam Berat Tembaga (Cu) pada Air, Sedimen, dan Kerang Darah (Anadara granosa) di Perairan Sungai Sayung dan Sungai Gonjol, Kecamatan Sayung, Kabupaten Demak. Journal Of Marine Research. Volume 1(2): 73-79

Darmono. 2001. Lingkungan Hidup dan Pencemaran, Hubungannya dengan Toksikologi Senyawa Logam. Penerbit Universitas Indonesia (UI Press). Jakarta

Gopalakrishnan, $\mathrm{K}$ and Udayakumar, R. 2017. Phytochemical content of leaf and stem of Marsilea quadrifolia (L.). Journal of Plant Science and Phytopathology

Ghasemi, K., Yosef, G. dan Mohammad A., 2009, Antioxidant Activity, Phenol And Flavonoid Contents of 13 Citrus Species Peels and Tissues, Pak. J. Pharm. Sci., 22(3), 277-281

Harborne. 1987. Metode Fitokimia, Penuntun Cara Modern Menganalisis Tumbuhan. Terjemahan; K. Padmawinata dan I. Sudiro. Institut Teknologi Bandung. Bandung

Hayati, A. 2012. Pengaruh Perendaman Asam Organik Terhadap Kelarutan Mineral Kerang Darah (Anadara granosa). Skripsi. Fakultas Perikanan dan Ilmu Kelautan. Institut Pertanian Bogor. Bogor

Kasprzak, M.M., Erxleben, A dan Ochocki, J. 2013. Properties and Applications of Flavonoid Metal Complexes. Journal Name .Royal Society of Chemistry Publishing

Marganof. 2003. Potensi Limbah Udang Sebagai Penyerap Logam Berat (Timbal, Kadmium, dan Tembaga) di Perairan. Unpublished. Pengantar ke 
Falsafah Sains Program Pascasarjana S3 IPB. Bogor. 8 pp.

Mohamad, E. 2011. Fitoremediasi Logam Berat Kadmium (Cd) Pada Tanah dengan Menggunakan Bayam Duri (Amaranthus spinosus L). Laporan Penelitian Pengembangan IPTEK Dana PNBP Tahun Anggaran 2012.

Pepsi, A., Ben, C.P and Jeeva, S. 2012. Phytochemical Analysis of Four Traditionally Important Aquatic Species. International Research Journal of Biological Sciences. Vol. 1(5), 66-69

Pokorny, J.N., Nedyalka Y., and Michael, G. 2001. Antioxidant in Food. Woodhead Publishing Ltd. England

Puspitasari, M.L., Tara V.W., Tri D.W., Jaya M,M., dan Nur I.P.N. 2016. Aktivitas Antioksidan Suplemen Herbal Daun Sirsak ( Annona muricata L.) dan Kulit Manggis (Garcinia mangostana L.):Kajian Pustaka. Jurnal Pangan dan Agroindustri 4(1):283-290

Putri, F.I. 2010. Kandungan Logam Berat $\mathrm{Hg}, \mathrm{Cd}$, Dan $\mathrm{Pb}$ pada Kerang Darah (Anadara Granosa) di Perairan Teluk Lada, Kabupaten Pandeglang, Banten. Skripsi. Fakultas Perikanan dan Ilmu Kelautan, Departemen Manajemen Sumberdaya Perairan. IPB. Bogor.
Redha, A. 2010. Flavonoid: Struktur, Sifat Antioksidan dan Peranannya Dalam Sistem Biologis. Jurnal Belian 9(2): 196-202.

Standarisasi Nasional Indonesia. 2009.

Batas Maksimum Pencemaran Logam Berat Dalam Pangan. Bandan Standarisasi Nasional. No 7387

Standar Nasional Indonesia. 2011. Penentuan Kadar Logam Berat Timbal $(\mathrm{Pb})$ dan Kadmium $(\mathrm{Cd})$ pada Produk Perikanan. Badan Standarisasi Nasional. No 2354.5

Standar Nasional Indonesia. 2016. Penentuan Kadar Logam Berat Merkuri (Hg) pada Produk Perikanan. Badan Standarisasi Nasional. No 2354.6

Suwignyo, S. 2005, Avertebrata Air, Penebar Swadaya, Jakarta.

Symonowicz, M and Kolanek, M. 2012. Flavonoids and Their Properties to Form Chelate Complexes. Biotechnol Food Science. Institute of General Food

Widiyanti, S. 2004. Reduksi Kadar Merkuri pada Kerang Hijau (Mytilus Viridis) Di Cilincing Jakarta melalui Metode Asam serta Pemanfaatannya dalam Produk Kerupuk. Departemen Teknologi Hasil Perikanan FPIKIPB.Bogor 